\title{
Prevalence of the Infectious Diseases of Goats in Sylhet District, Bangladesh
}

\author{
Saiful Islam ${ }^{1 *}$, Mst Rubaiat Nazneen Akhand ${ }^{2}$, Maruf Billah Khan ${ }^{1}$, Mohammed Kawser Hossain ${ }^{3}$
}

${ }^{1}$ Department of Physiology, Sylhet Agricultural University, Sylhet-3100, Bangladesh

${ }^{2}$ Department of Biochemistry and Chemistry, Sylhet Agricultural University, Sylhet-3100, Bangladesh

${ }^{3}$ Department of Surgery and Theriogenology, Sylhet Agricultural University, Sylhet-3100, Bangladesh

DOI: $\underline{10.36347 / \text { sjavs.2021.v08i04.001 }}$

| Received: 13.03.2021 | Accepted: 17.04.2021 | Published: 24.04.2021

*Corresponding author: Saiful Islam

Abstract

Original Research Article

Background and Aim: Goats play a vital role to provide nutrition as well as the development of the national economy in Bangladesh. The goats are infected by various diseases which may decline their health conditions. The present study was conducted to determine the prevalence of infectious diseases of goats in Sylhet district, Bangladesh. Materials and Methods: The current study was conducted in the District Veterinary hospital, Sylhet, Sylhet between March 2019 to February 2020. About 1230 goats were recorded throughout the study. The total diseases were analyzed based on clinical signs, patient owners complain and laboratory examinations. The prevalence was measured according to sex, age, season and breed of the goats which were studied. Statistical analysis was performed by Chi-square test. Results: In this study, 1230 goats were found to be diseased at Sylhet veterinary hospital, Sylhet. The highest prevalence was recorded with bacterial disease $(34.39 \%)$ followed by mixed infection $(26.1 \%)$, parasitic disease (19.84\%), viral (19.68\%). The highest prevalence was found with PPR (18.54\%), upper respiratory infection $(14.31 \%)$, pneumonia $(9.37 \%)$, diarrhea $(8.78 \%)$, keratoconjunctivitis $(5.69 \%)$, shipping fever $(5.37 \%)$ mastitis $(4.63 \%)$, anaplasmosis $(4.07 \%)$ and arthritis $(3.9 \%)$. Prevalence of diseases in female goat $(65 \%)$ was significantly higher than in male goat $(35 \%)$. Infection rate of goat was significantly higher in over 24 months of age (29\%) followed by 6-12 month (24\%), 0-6 month (20\%), 13-16 month $(17 \%)$ and 19-24 month $(10 \%)(\mathrm{P}>0.001)$. The percentage of disease in goats was higher in rainy season $(42 \%)$ compared to in winter season $(31 \%)$ and in winter season $(27 \%)$. The prevalence of diseases in goat with breed variation. The prevalence of infectious disease in goats was relatively higher in black Bengal goat (61\%) followed by in local $(23 \%)$ and in Jamunapari (27\%). Conclusion: These results show the high rate of numerous infectious diseases in the goats of Sylhet area. Therefore, immediate action will be taken by the government, veterinarian, private organizations for preventing and reducing the loss.

Keywords: Goat, prevalence, diseases, age, sex, season.

Copyright ( $\odot 2021$ The Author(s): This is an open-access article distributed under the terms of the Creative Commons Attribution 4.0 International License (CC BY-NC 4.0) which permits unrestricted use, distribution, and reproduction in any medium for non-commercial use provided the original author and source are credited.

\section{INTRODUCTION}

Goat is one of the most indispensable small ruminants in Bangladesh due to high rates of prolificacy, short generation intervals and the ease with which the goats and their produced can be marketed. Goat contributes in developing rural economy and as well as the reduction of poverty in Bangladesh. Goat is called as "poor man's cow" because poor farmers, labors and misery women who cannot pay for rearing cattle, rearing goat with very little capital investment can be beneficial to them. Goat is reared easily, profile in climate especially in arid zones [1]. As a subordinate occupation, farmers rear goats to supplement their livelihood. Goat farming can play vital role in improving farmers living economy and also provides the main dietary animal protein to promote national health. Moreover, in Bangladesh, meat and skin of goats contribute about $38 \%$ and $28 \%$ of total livestock meat and skin production according to the food and Agricultural Organization (FAO) [2].

Currently, about 26.10 goats are recorded in Bangladesh [3] and more than $90 \%$ of the total goat population is Black Bengal Goat (BBG), which is reared for their high fertility rate, prolific, early sexual maturity, adjust quickly to hot environments and excellent meat and skin quality $[4,5]$. The About $80.5 \%$ farmers are used semi-intensive are used for rearing, while limited farmers around $7.3 \%$ used confinement systems of rearing and approximate $12.2 \%$ farmers used the un-confinement system in rearing of goats [6]. 
However, numerous infectious and noninfectious diseases are commonly occurring in goats which considered as a severe threat of existing animals in Bangladesh. Infectious diseases are not only affecting enormous loss in the farmer but they also can hamper our national economy in Bangladesh [7]. In Bangladesh, the occurrences of various diseases become conducive because of practicing unhealthy management and adverse environmental condition [8]. The occurrence of diseases also hampers productivity and the economy of goat farming. However, there is no precise statistical data available related to infectious diseases in goats in Sylhet district in Bangladesh Therefore, these data could be helpful for researcher, veterinarian, private practitioners, service providers for taking strategic plan to prevent and control measures of occurring infectious diseases in goats. Considering the above situations, the current study was designed to investigate the prevalence of infectious diseases in goats in Sylhet district, Bangladesh.

\section{MATERIALS AND METHODS Study Area and Period}

The present study was conducted in District Veterinary Hospital, Sylhet between March 2019 and February 2020. The necessary information and data were collected from registered record book of the veterinary hospital where all diseased goats were brought for treatment.

\section{Sample Size}

A total number of 1230 goats were noted and those the number of animals in winter (NovemberFebruary), summer (March-June) and rainy (JulyOctober) season were 398, 326 and 495, respectively. The prevalence was measured according to age, breed and season of the goats which were studied.

\section{Physical Examination}

During the study period, suspected goats were examined with physically appearance including posture, gait, body temperature, respiration rate, body condition score (BCS), feaces, any swelling, wound, abscess and abnormal outgrowth found in the body surface of goats. Moreover, the affected goats were observed to find any abnormality of muscles, udder, and mouth and various joints through palpation. Any defect of respiratory tract and heart beat were observed by using stethoscope and male and female genital tract were examined for the presence of any abnormality.

\section{Clinical investigation and diagnosis}

Throughout the study period, suspected goats were documented on the basis of sex, age, season and breed by sensibly collected information from farmers or animals' owners according to Balamurugan et al., [9]. After performing visual examination, infected goats were examined specifically through auscultation, palpation; percussion and needle puncture as well. The clinical investigation was conducted on the basis of disease history and symptoms, and laboratory techniques were used [10]. For specific bacterial, viral and fungal diseases were observed on the basis of specific clinical signs and gross lesions [11, 12]. In some cases, confirmatory diagnosis was done by cultural and biochemical characteristics of causal organisms following standard procedure. For parasitic disease diagnosis, parasitic diseases were detected on the basis of clinical history, clinical signs and symptoms and faeces examination [13]. Gross investigation of faces was prepared for the detection of living or dead worms or for the detection of the segments of tapeworms. The suspected goats were inspected for the presence of any visible ectoparasites which were identified followed by wall $\&$ Shearer [14].

\section{Statistical analysis}

Chi-square tests were used to determine the differences of prevalence in gender, age, season and breed of the goats. $P$ values of $<0.05$ were considered significantly in this study.

\section{RESULTS \\ Overall prevalence of diseases of goats}

The study period, in whole year, the highest percentage was observed in bacterial disease (34\%) followed by mixed infection $(26 \%)$, viral and parasitic infection (20\%) (Fig-1). The most prevalence of diseases was noted in PPR $(18.54 \%)$ and the least in Listeriosis $(0.73 \%)$. Prevalence of other diseases like Upper Respiratory Tract infection (URT), pneumonia, diarrhoea (infectious), keratoconjunctivitis, shipping fever, mastitis, anaplasmosis, arthritis and abortion (infectious) were $14.31 \%, 9.19 \%, 8.78 \%, 5.69 \%$, $5.37 \%, 4.63 \%, 4.07 \%, 3.9 \%$ and $3.01 \%$ respectively. Lower prevalence was found in the case of contagious ecthyma $(1.14 \%)$, tetanus $(1.38 \%)$, coccidiosis $(1.87 \%)$, foot $\operatorname{rot}(1.95 \%)$, urinary tract infection (2.2\%), actinomycosis $(2.28 \%)$, dermatitis $(2.36 \%)$, babesiosis $(2.68 \%)$ and metritis $(2.76 \%)$ (Table-1).

\section{Sex-Wise Variation}

We classified goats in two categories, male and female according sex variation. The no. of 1230 goats were observed in which 429 were male and 801 were female (Table-2). The highest percentage was observed in female (65\%) compared to male goat $(35 \%)$ (Fig-2). In viral infections, it was found that the most prevalence was PPR in both male $(20.75 \%)$ and female $(17.35 \%)$. In case of male animal, the highest prevalence was found in PPR $(20.75 \%)$ and least in listeriosis $(0.7 \%)$. In female, the highest prevalence was found in PPR $(17.35 \%)$ and lowest in both tetanus and listeriosis $(0.75 \%)$. Among the bacterial diseases, the incidence rate of pneumonia was the top in both male and female at the rate of $11.66 \%$ and $7.87 \%$ respectively. In the parasitic diseases, the prevalence of anaplasmosis found the most in male (4.9\%) and 
keratoconjuctivitis in female (6.2\%). In mixed infections, the infection rate of diarrhoea in male was $10.49 \%$ and upper respiratory tract infection in female $(14.23 \%)$.

\section{Age-Wise Variation}

The no. of 1230 goats were observed in which 346 were in 0-6 month, 294 were in 7-12 month, 215 were in 13-18 month, 134 were in 19-24 month and 241 were in $<24$ month (Table-3). The most percentage was detected in above 24 month of age (29\%) and the least in 19-24 month (10\%) (Fig-3). In viral diseases, the most prevalence of PPR $(23.47 \%)$ was in 7-12-month age, whereas the lowest in 19-24-month age (9.70\%). In bacterial diseases, the prevalence of mastitis was $16.60 \%$ of $>24$-month age but in parasitic and mixed infection the highest infection rate was in anaplasmosis $(12.69 \%)$ of 19-24-month age group and upper respiratory tract infection $(18.37 \%)$ in $7-12$-month age group respectively. In 0-6-month age group, the highest prevalence was found in case of PPR $(21.10 \%)$ and lowest prevalence was found both for dermatitis $(1.16 \%)$ and listeriosis (1.16\%). In 7-12-month of age, the highest infection rate of PPR was $23.47 \%$ and the least in coccidiosis $(0.34 \%)$. In 13-18-month age, the highest and lowest prevalence was PPR (18.14\%) and listeriosis $(0.47 \%)$ respectively. In 19-24-month, the most incidence rate was observed in anaplasmosis $(12.69 \%)$ and the least in foot rot, tetanus, coccidiosis and dermatitis at the rate of $0.75 \%$. In $>24$-month age, the most occurrence of disease was found in mastitis
$(16.60 \%)$ and the least in tetanus $(0.83 \%)$ and listeriosis $(0.83 \%)$.

\section{Season-Wise Variation}

The no. of 1230 goats was observed in which 381 were in winter season and 337 were in summer season and 512 were in rainy season (Table-4). The most prevalence was found in rainy season (42\%) followed by winter $(31 \%)$ and summer season $(27 \%)$ (Fig-4). In winter season, the highest occurrence was observed in PPR $(21 \%)$ and the lowest in foot rot $(1.05 \%)$, listeriosis $(1.05 \%)$ and babesiosis (1.05\%). In summer season, the most percentage was found in PPR $(16.02 \%)$ and the least in contagious ecthyma $(0.03 \%)$. In rainy season, the highest prevalence was found in case of PPR $(18.36 \%)$ and the lowest in listeriosis $(0.59 \%)$.

\section{Breed-Wise Variation}

The no. of 1230 goats was observed in which 753 were Black Bengal breed, 199 were Jamunapari breed and 278 were Local breed (Table-5). The highest prevalence was observed in Black Bengal goat (61\%) and the least in Jamunapari breed (16\%) (Fig-5). In Black Bengal goat, the highest prevalence was found in PPR $(16.07 \%)$ and the lowest in contagious ecthyma $(0.8 \%)$. In Jamunapari goat, the highest occurrence rate was in PPR $(25.13 \%)$ and the lowest in urinary tract infection $(0.5 \%)$ but not a single case was found in listeriosis. In local goat, the highest percentage was found in case of Pest des petis ruminant $(20.50 \%)$ and lowest prevalence was found in case of listeriosis $(0.72 \%)$.

Table-1: Overall prevalence of different infectious diseases of goat.

\begin{tabular}{|l|l|l|l|}
\hline & Diseases & No of positive cases & Prevalence (\%) \\
\hline Viral & PPR & 228 & 18.54 \\
\hline & Contagious ecthyma & 14 & 1.14 \\
\hline Bacterial & Shipping fever & 66 & 5.37 \\
\hline & Pneumonia & 113 & 9.19 \\
\hline & Actinomycosis & 28 & 2.28 \\
\hline & Foot rot & 24 & 1.95 \\
\hline & Tetanus & 17 & 1.38 \\
\hline & Listeriosis & 9 & 0.73 \\
\hline & Mastitis & 57 & 4.63 \\
\hline & Metritis & 34 & 2.76 \\
\hline & Urinary tract infection & 27 & 2.2 \\
\hline & Arthritis & 48 & 3.9 \\
\hline & Dermatitis & 29 & 2.36 \\
\hline & Anaplasmosis & 50 & 4.07 \\
\hline & Babesiosis & 33 & 2.68 \\
\hline & Coccidiosis & 23 & 1.87 \\
\hline & Fungal infection & 39 & 3.17 \\
\hline & Keratoconjunctivitis & 70 & 5.69 \\
\hline & Diarrhoea & 108 & 8.78 \\
\hline & Abortion & 37 & 3.01 \\
\hline & URT infection & 176 & 14.31 \\
\hline
\end{tabular}

Statistical analysis was performed using Chi-square test 
Table-2: Sex-wise prevalence of infectious diseases of goat.

\begin{tabular}{|c|c|c|c|c|}
\hline & \multirow[t]{2}{*}{ Diseases } & \multicolumn{2}{|l|}{ Sex } & \multirow[t]{2}{*}{ P-value } \\
\hline & & $\begin{array}{l}\text { Male } \\
(n=429)\end{array}$ & Female $(n=801)$ & \\
\hline & & $\begin{array}{l}\text { Prevalence } \\
(\%)\end{array}$ & $\begin{array}{l}\text { Prevalence } \\
(\%)\end{array}$ & \\
\hline \multirow[t]{2}{*}{ Viral } & PPR & 20.75 & 17.35 & 0.076197678 \\
\hline & Contagious ecthyma & 1.63 & 0.87 & \\
\hline \multirow[t]{10}{*}{ Bacterial } & Shipping fever & 6.99 & 4.49 & $7.62312 \mathrm{E}-11$ \\
\hline & Pneumonia & 11.66 & 7.87 & \\
\hline & Actinomycosis & 3.26 & 1.75 & \\
\hline & Foot rot & 1.86 & 2 & \\
\hline & Tetanus & 2.56 & 0.75 & \\
\hline & Listeriosis & 0.7 & 0.75 & \\
\hline & Mastitis & 0 & 7.12 & \\
\hline & Metritis & 0 & 4.24 & \\
\hline & Urinary tract infection & 2.56 & 2 & \\
\hline & Arthritis & 4.2 & 3.75 & \\
\hline \multirow[t]{6}{*}{ Parasitic } & Dermatitis & 2.8 & 2.12 & 0.032856387 \\
\hline & Anaplasmosis & 4.9 & 3.62 & \\
\hline & Babesiosis & 0.93 & 3.62 & \\
\hline & Coccidiosis & 2.56 & 1.5 & \\
\hline & Fungal infection & 3.03 & 3.25 & \\
\hline & Keratoconjunctivitis & 4.66 & 6.24 & \\
\hline \multirow[t]{3}{*}{ Mixed infection } & Diarrhoea(infectious) & 10.49 & 7.87 & 1.65582E-05 \\
\hline & Abortion(infectious) & 0 & 4.62 & \\
\hline & URT infection & 14.45 & 14.23 & \\
\hline
\end{tabular}

Statistical analysis was performed using Chi-square test

Table-3: Age-wise prevalence of different infectious diseases of goat

\begin{tabular}{|c|c|c|c|c|c|c|c|}
\hline & \multirow[t]{2}{*}{ Diseases } & \multicolumn{5}{|c|}{ Age (months) } & \multirow[t]{2}{*}{ P-value } \\
\hline & & $\begin{array}{l}0-6 \\
(n=346)\end{array}$ & $\begin{array}{l}7-12 \\
(n=294)\end{array}$ & $\begin{array}{l}13-18 \\
(n=215)\end{array}$ & $\begin{array}{l}19-23 \\
(n=134)\end{array}$ & $\begin{array}{l}>24 \\
(n=241)\end{array}$ & \\
\hline & & $\begin{array}{l}\text { Pre } \\
\text { valence } \\
(\%)\end{array}$ & $\begin{array}{l}\text { Pre } \\
\text { valence } \\
(\%)\end{array}$ & $\begin{array}{l}\text { Pre } \\
\text { valence } \\
(\%)\end{array}$ & $\begin{array}{l}\text { Pre } \\
\text { valence } \\
(\%)\end{array}$ & $\begin{array}{l}\text { Pre } \\
\text { valence } \\
(\%)\end{array}$ & \\
\hline \multirow[t]{2}{*}{ Viral } & PPR & 21.10 & 23.47 & 18.14 & 9.70 & 14.11 & 0.001562443 \\
\hline & Contagious ecthyma & 1.73 & 1.36 & 0.93 & 1.49 & 0.00 & \\
\hline \multirow[t]{10}{*}{ Bacterial } & Shipping fever & 7.23 & 5.78 & 5.12 & 1.49 & 4.56 & $7.37418 \mathrm{E}-22$ \\
\hline & Pneumonia & 12.43 & 10.20 & 6.98 & 8.21 & 5.81 & \\
\hline & Actinomycosis & 3.18 & 3.06 & 2.79 & 1.49 & 0.00 & \\
\hline & Foot rot & 1.45 & 1.02 & 2.33 & 0.75 & 4.15 & \\
\hline & Tetanus & 2.02 & 1.70 & 0.93 & 0.75 & 0.83 & \\
\hline & Listeriosis & 1.16 & 0.68 & 0.47 & 0.00 & 0.83 & \\
\hline & Mastitis & 0.00 & 0.00 & 6.05 & 2.99 & 16.60 & \\
\hline & Metritis & 2.02 & 1.70 & 2.33 & 4.48 & 4.56 & \\
\hline & Urinary tract infection & 0.00 & 2.38 & 2.79 & 6.72 & 2.07 & \\
\hline & Arthritis & 2.02 & 7.48 & 4.65 & 2.99 & 2.07 & \\
\hline \multirow[t]{6}{*}{ Parasitic } & Anaplasmosis & 0.00 & 4.08 & 6.05 & 12.69 & 3.32 & $1.61852 \mathrm{E}-15$ \\
\hline & Babesiosis & 0.87 & 1.36 & 0.93 & 8.96 & 4.98 & \\
\hline & Coccidiosis & 2.60 & 0.34 & 0.93 & 0.75 & 4.15 & \\
\hline & Fungal infection & 4.62 & 2.38 & 1.86 & 3.73 & 2.90 & \\
\hline & Keratoconjunctivitis & 3.47 & 2.72 & 9.77 & 9.70 & 6.64 & \\
\hline & Dermatitis & 1.16 & 2.72 & 3.72 & 0.75 & 3.32 & \\
\hline \multirow[t]{3}{*}{ Mixed } & Diarrhoea(infectious) & 17.34 & 9.18 & 4.19 & 4.48 & 2.49 & $2.73713 \mathrm{E}-17$ \\
\hline & Abortion(infectious) & 0.00 & 0.00 & 6.98 & 6.72 & 5.39 & \\
\hline & URT infection & 15.61 & 18.37 & 12.09 & 11.19 & 11.20 & \\
\hline
\end{tabular}

Statistical analysis was performed using Chi-square test 
Table-4: Season-wise prevalence of different infectious diseases of goat.

\begin{tabular}{|c|c|c|c|c|c|}
\hline & Diseases & Season & & & P-value \\
\hline & & $\begin{array}{l}\text { Winter } \\
(n=381)\end{array}$ & $\begin{array}{l}\text { Summer } \\
(n=337)\end{array}$ & $\begin{array}{l}\text { Rainy } \\
(\mathrm{n}=512)\end{array}$ & \\
\hline & & $\begin{array}{l}\text { Prevalence } \\
(\%)\end{array}$ & $\begin{array}{l}\text { Prevalence } \\
(\%)\end{array}$ & $\begin{array}{l}\text { Prevalence } \\
(\%)\end{array}$ & \\
\hline Viral & PPR & 21.00 & 16.02 & 18.36 & 0.159647 \\
\hline & Contagious ecthyma & 1.57 & 0.30 & 1.37 & \\
\hline Bacterial & Shipping fever & 4.99 & 4.45 & 6.25 & 0.066601 \\
\hline & Pneumonia & 6.56 & 13.06 & 8.59 & \\
\hline & Actinomycosis & 2.10 & 2.37 & 2.34 & \\
\hline & Foot rot & 1.05 & 2.37 & 2.34 & \\
\hline & Tetanus & 1.31 & 0.59 & 1.95 & \\
\hline & Listeriosis & 1.05 & 0.59 & 0.59 & \\
\hline & Mastitis & 4.46 & 6.82 & 3.32 & \\
\hline & Metritis & 3.67 & 2.08 & 2.54 & \\
\hline & Urinary tract infection & 2.36 & 2.37 & 1.95 & \\
\hline & Arthritis & 4.99 & 3.86 & 3.13 & \\
\hline Parasitic & Dermatitis & 1.31 & 2.08 & 3.32 & 0.018617 \\
\hline & Anaplasmosis & 3.94 & 5.04 & 3.52 & \\
\hline & Babesiosis & 1.05 & 4.15 & 2.93 & \\
\hline & Coccidiosis & 1.57 & 2.08 & 1.95 & \\
\hline & Fungal infection & 3.67 & 2.97 & 2.93 & \\
\hline & Keratoconjunctivitis & 7.09 & 2.67 & 6.64 & \\
\hline Mixed & Diarrhoea(infectious) & 5.51 & 9.50 & 10.74 & 0.011656 \\
\hline & Abortion(infectious) & 4.46 & 2.37 & 2.34 & \\
\hline & URT infection & 16.27 & 14.24 & 12.89 & \\
\hline
\end{tabular}

Statistical analysis was performed using Chi-square test

Table-5: Breed-wise prevalence of different infectious diseases of goat

\begin{tabular}{|c|c|c|c|c|c|}
\hline & \multirow[t]{2}{*}{ Diseases } & \multicolumn{3}{|l|}{ Breed } & \multirow[t]{2}{*}{ P-value } \\
\hline & & $\begin{array}{l}\text { Black Bengal } \\
(n=753)\end{array}$ & $\begin{array}{l}\text { Jamunapari } \\
(n=199)\end{array}$ & $\begin{array}{l}\text { Local } \\
(n=278)\end{array}$ & \\
\hline & & $\begin{array}{l}\text { Prevalence } \\
(\%)\end{array}$ & $\begin{array}{l}\text { Prevalence } \\
(\%)\end{array}$ & $\begin{array}{l}\text { Prevalence } \\
(\%)\end{array}$ & \\
\hline \multirow[t]{2}{*}{ Viral } & PPR & 16.07 & 25.13 & 20.50 & 0.00662 \\
\hline & Contagious ecthyma & 0.80 & 2.01 & 1.44 & \\
\hline \multirow[t]{10}{*}{ Bacterial } & Shipping fever & 4.91 & 5.53 & 6.47 & 0.647052 \\
\hline & Pneumonia & 9.43 & 7.04 & 10.07 & \\
\hline & Actinomycosis & 2.26 & 2.51 & 2.16 & \\
\hline & Foot rot & 1.59 & 3.02 & 2.16 & \\
\hline & Tetanus & 1.33 & 1.51 & 1.44 & \\
\hline & Listeriosis & 0.93 & 0.00 & 0.72 & \\
\hline & Mastitis & 5.71 & 3.02 & 2.88 & \\
\hline & Metritis & 3.19 & 2.01 & 2.16 & \\
\hline & Urinary tract infection & 2.52 & 0.50 & 2.52 & \\
\hline & Arthritis & 3.98 & 3.52 & 3.96 & \\
\hline \multirow[t]{6}{*}{ Parasitic } & Dermatitis & 2.39 & 3.52 & 1.44 & 0.706753 \\
\hline & Anaplasmosis & 3.72 & 3.02 & 5.76 & \\
\hline & Babesiosis & 2.66 & 3.52 & 2.16 & \\
\hline & Coccidiosis & 1.99 & 1.51 & 1.80 & \\
\hline & Fungal infection & 3.59 & 3.02 & 2.16 & \\
\hline & Keratoconjunctivitis & 5.71 & 5.53 & 5.76 & \\
\hline \multirow[t]{3}{*}{ Mixed } & Diarrhoea(infection) & 8.63 & 9.55 & 8.63 & 0.452838 \\
\hline & Abortion(infection) & 2.79 & 3.02 & 3.60 & \\
\hline & URT infection & 15.80 & 11.56 & 12.23 & \\
\hline
\end{tabular}

Statistical analysis was performed using Chi-square test 


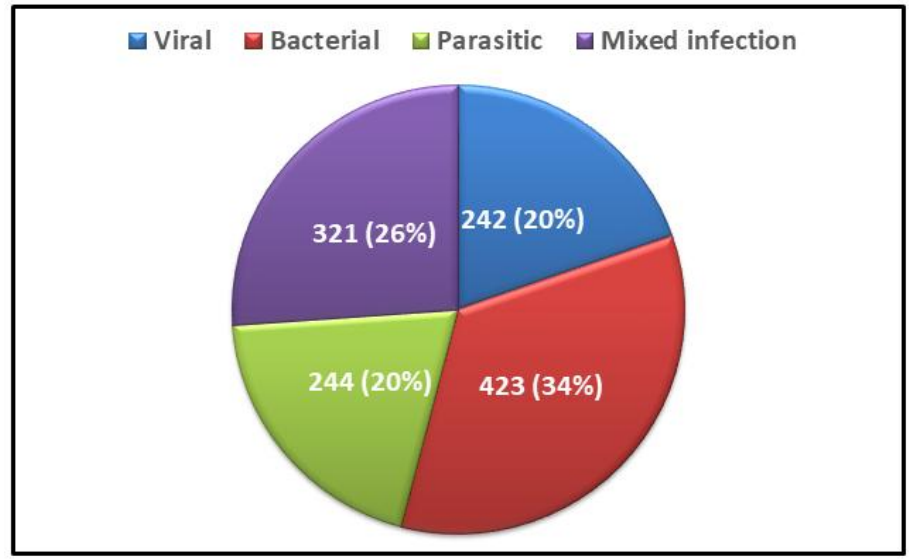

Fig-1: Percentage of diseases according to causal agent

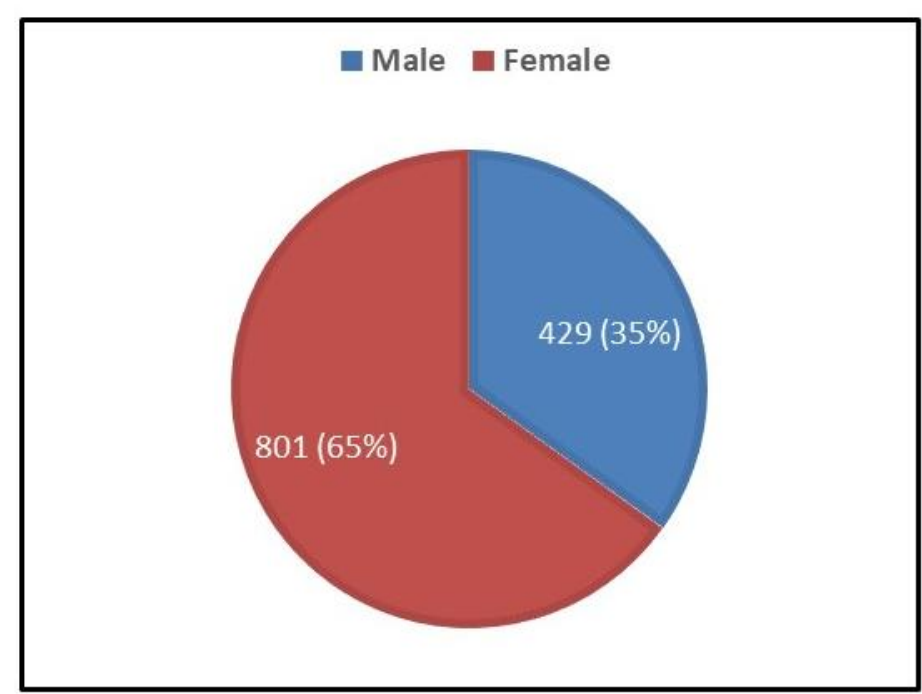

Fig-2: Percentage of diseases according to sex

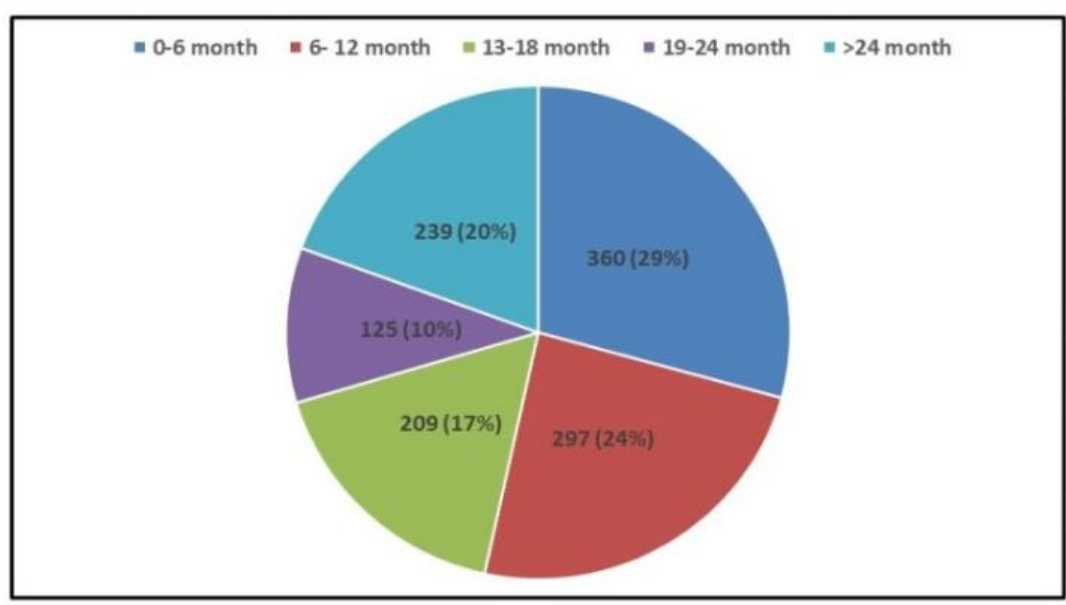

Fig-3: Percentage of diseases according to age 


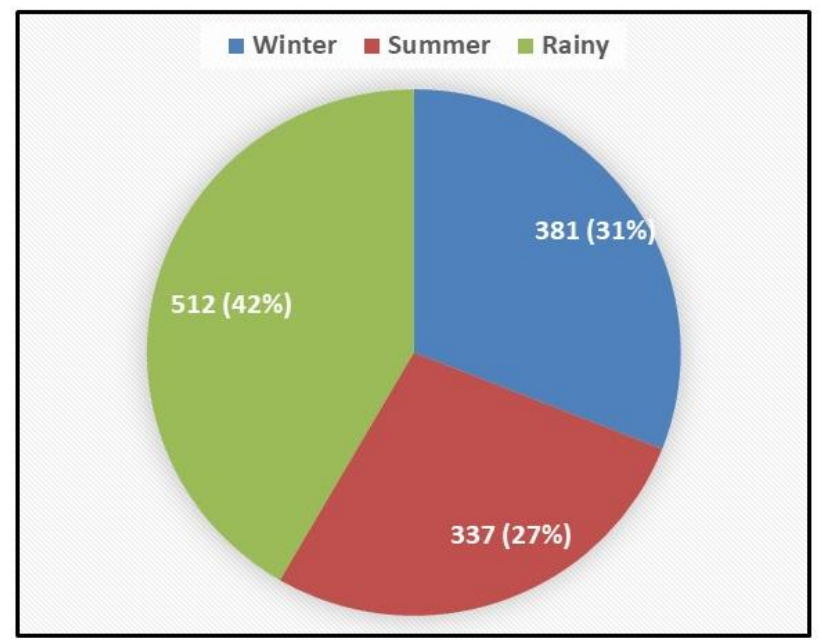

Fig-4: Percentage of diseases according to season

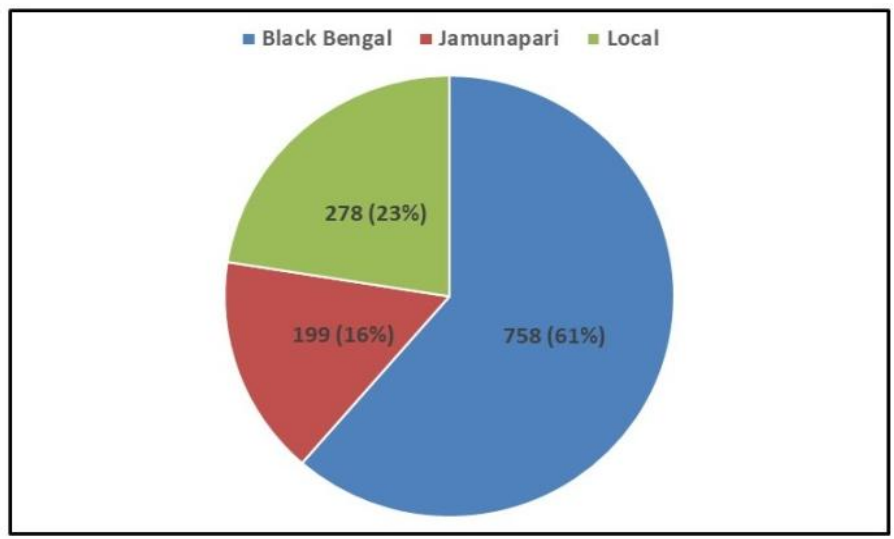

Fig-5: Percentage of diseases according to breed

\section{DISCUSSION}

The goat is affected with diseases, which is caused by viruses, bacteria, parasites and noninfectious agents [15]. Among the viral diseases of the goat, the current study represented $18.52 \%$ prevalence of PPR in goat which is parallel with other investigations $[16,17]$ recorded the prevalence of PPR in goat was $13.72 \%$ and $13.74 \%$ respectively. In North east India, however, the occurrence of PPR was about $45.2 \%$. The variation might be due to various geographical distribution and animal husbandry [18]. This study shown that the prevalence of PPR was comparatively higher in male $(20.75 \%)$ than that of female $(17.35 \%)$ and also presented the infection rate of PPR was highest in winter $(21 \%)$ and summer $(16.02 \%)$ season. Ahsan et al., [17] was found the similar results of their study. Moreover, in 6-12 month's age group, the prevalence was detected highest $(23.47 \%)$ followed by $12-18$ month's (18.14\%) and above 24 months (14.11\%) age group. This study illustrated that young goats was more susceptible to PPR than the adult and other studies also represented similar findings $[17,19,20]$. The young animals might be more susceptible because of undernourishment, lack of immunity and poor husbandry. Additionally, the prevalence of PPR was considerably higher in cross breed, jamunapari goat $(25.13 \%)$ and followed by local $(20.50 \%)$ and black Bengal $(16.07 \%)$ goats and other study showed similar results [21]. The increased susceptibility to jamunapari goat might be due to weak immunity and poor husbandry.

Among the bacterial diseases, respiratory infections mainly pneumonia, are a serious and common disease in goats. In our study, among the bacterial diseases, pneumonia was observed to prevalent in $9.19 \%$ goats which was concurrent with other investigations [17] whereas it was revealed $17.11 \%$ in Ethiopia [22]. Other studies reported slightly lower prevalence $9.6 \%$ and $8.28 \%$ pneumonia in goats in Magura and Sylhet respectively [23, 24]. The prevalence of pneumonia was considerably higher in male $(11.66 \%)$ than that of female $(7.89 \%)$ goat and almost similar result was reported by Enyiew et al., [21]. Among study goats, 0-6 months (12.43\%) age group was more susceptible pneumonia than 18-23 months $(8.21 \%)$ and above 24 months $(5.21 \%)$. The similar result was described by Ahsan et al., [17]. The highest incidence of pneumonia was observed in summer $(13.06 \%)$ followed by $8.59 \%$ in winter in rainy and $6.56 \%$ in winter. In contrast, the most prevalence of 
pneumonia was detected in winter season and the lowest in rainy season [17] and Sardar et al., [25] revealed that the lowest occurrence of pneumonia in summer season $(1.02 \%)$. This study reported the prevalence of shipping fever was the second highest among bacterial diseases, whereas arthritis was second highest in young age of goat. In sex variation, shipping fever and arthritis were significantly higher in male than that of female goat $(\mathrm{P}>0.001)$ and in young age was considerably more susceptible than the adult goats. The highest prevalence of shipping fever was $6.25 \%$ in rainy season whereas the lowest rate was detected in summer. In breed variation, local goat was more affected by shipping fever followed by cross breed and black bengal goat. In actinomycosis, male was significantly higher than female and young age was considerably higher than adult. The prevalence of tetanus was significantly higher in male $(2.56 \%)$ than that of female $(0.75 \%)$ goat and young was more susceptible than adult. The prevalence was varied according to the season where it was $1.95 \%$ in rainy and $1.31 \%$ in winter and $0.59 \%$ in summer season, whereas the prevalence was higher in winter followed by rainy season and no case was detected in summer [17]. However, the slightly higher prevalence of tetanus in summer season $[24,26]$. The variation might be because of geographical position and management system of goats rearing.

Mastitis is a serious bacterial disease, which is one of the leading causes of culling in goat operations [27]. The present study represented at $4.63 \%$ prevalence of mastitis in goats and similar result revealed by Gabli et al., [28] in Eastern Algeria. In contrary, other studies detected slightly lower rate of mastitis in goats, with $1.55 \%$ [17] and $1.6 \%$ mastitis in goat Karim et al., 2014. The prevalence of mastitis was peak in summer and lowest in rainy season whereas the frequency was higher in rainy season [17].

The incidence rate of mastitis was found to be increased with age as the present study recorded $16.6 \%$ cases in the above 24 months' age and $2.99 \%$ in $19-23$ months' age group and finding was similar as Ahsan et al., [17]. In breed variation, the current study the prevalence of mastitis was high in black bengal goat and low in local goat. The variation might be due to malnutrition, poor management system of goat.

Parasites pose a significant threat to the goat health that can damage the gut resulting in reduced growth rates and reproductive performance; less productive animals in terms of meat, fiber and milk and even death [29]. The current study represented that the prevalence of parasitic infestation was recorded $19.84 \%$ in goat. The frequency of parasitic diseases was significantly higher in female (20.35) than that of male goat $(18.88 \%)$. It could associate with higher number of female goats as compared to male in the study site.
Additionally, it might also partly associate with the low level of immunity of female animals.

The parasitic diseases were significantly increasing with their age and which was seasonally distributed rainy $(21.99 \%)$ and summer $(18.99 \%)$ and winter $(18.63 \%)$. Other studies stated that the incidence of parasitic diseases was $29.00 \%$ in summer, $39.35 \%$ in rainy and $18.10 \%$ in winter [17]. In breed variation, the occurrence of parasitic diseases was $20.12 \%$ in Jamunapari, $20.06 \%$ in black begal and $19.08 \%$ in local goat. The difference might be owing to geographical distribution and husbandry in goat and lack of awareness about the importance of deworming might be the underlying cause to high worm infestation.

The present study reported that the frequency of diarrhea was considerably higher in male than female, and was significantly higher in young age than adult. In season variation, the prevalence of diarrhea was greater in rainy season shadowed by summer and winter. The rainy season goats were more susceptible to various diseases because of environmental problems and poor rearing system. This result was similar with other studies $[19,20]$. The jamunapari breed was more susceptible to diarrhea than black Bengal and local breed (Table-5). The current study the occurrence of upper respiratory was significantly greater in young age group that that of adult ( $p>0.001^{*}$ ) and seasonally $16.27 \%$ in winter, $14.24 \%$ in summer and $12.89 \%$ in rainy season. The variation might be due to high dust particles in air during winter season.

\section{CONCLUSION}

Worldwide, infectious diseases are measured as a key problem in the health condition and production ability of goats. This study, it was reported that goats were most susceptible to bacterial disease than other diseases. Among the diseases, female was more affected to disease than male goat and the highest prevalence was detected in rainy season. The prevalence of diseases also varies with the age and breed of goats. These findings will assist to know about sex-wise, age-wise, season-wise and breed-wise variation of various diseases of goat in Sylhet district and will assist to application suitable way of prevention procedures against goats' diseases.

\section{Authors' Contributions}

Co- authors designed the experiment and reviewed the manuscript. S Islam, MRN Akhand and MB Khan performed the experiment, collected samples, examined the data, and inscribed the original draft. All authors recite and accepted the final manuscript.

Acknowledgements: We are cordially admitted to the Department of Physiology, SAU, Sylhet, for providing financial and logistic supports of successfully executions throughout study. 
Conflict of Interest: The authors state that there is contending interests.

\section{REFERENCES}

1. Banerjee GC. A textbook of animal husbandry. Oxford and IBH publishing; 2018 Apr 30.

2. Sarker S, Islam MH. Prevalence and risk factor assessment of Peste des petits ruminants in goats in Rajshahi, Bangladesh. Veterinary world. 2011 Dec 1;4(12):546.

3. DLS. Annual Report of Directorate of Livestock Service 2017-2018, Bangladesh.

4. Hussain, SS. A study on the Productive and Genetic potential of Black Bengal Goats, PhD Thesis.1993. Bangladesh Agricultural University.

5. Amin MR, Hussain SS, Islam ABMM. Reproductive peculiarities and litter weight in different genetic groups of Black Bengal does. Asian Austral Journal of Animal Science. 2001;14(3):197-301.

6. Islam MR, Amin MR, Kabir AK, Ahmed MU. Comparative study between semi-intensive and scavenging production system on the performances of Black Bengal goat. Journal of the Bangladesh Agricultural University. 2009;7(452-2016-35476).

7. Hussain SS. Sustainable genetic improvement of economic traits of Black Bengal goats through selective and cross breeding. Bangladesh Agricultural University Research Progress. 1999. 10: 72-80.

8. Ndegwa EN, Munyua SJ, Mulei CM. Prevalence of microorganisms associated with udder infections in dairy goats on small-scale farms in Kenya. Journal of the South African Veterinary Association. 2001 Jun 1;72(2):97-8.

9. Balamurugan V, Saravanan P, Sen A, Rajak KK, Venkatesan G, Krishnamoorthy P, Bhanuprakash V, Singh RK. Prevalence of peste des petits ruminants among sheep and goats in India. Journal of veterinary science. 2012 Sep;13(3):279.

10. Rosenberger G. Clinical Examination of Cattle. $2^{\text {nd }}$ edn. Verlag Poul Parey, Germany. 1979.

11. Jones TC, Hunt RD, Kimg NW. Veterinary Pathology. Williams \& Wilkins, A Waverly Company. Sixth Edition. 1996.

12. Khan CM. The Merck Veterinary Manual. Merck Sharp \& Dohme Corporation. USA. 10th Edition. 2000.

13. Blood DC, Radostits OM. Veterinary Medicine .7th edn. Balliere and Tindal, London.1989.

14. Wall R and Shearer D. Veterinary Entomology, 1st edition, Chapman and Hall. London, UK. 1997. pp 265 and 290.

15. Taylor WP. The distribution and epidemiology of peste des petits ruminants in the sultanate of oman. Veterinary Microbiology. 1984., 22:341-352.

16. Poddar S, Tuli DE, Sultana J, Akter S, Alauddin M. Prevalence of Peste des petits ruminants in Goat at Upizalla Veterinary Hospital, Pirojpur Sadar, Bangladesh. Turkish Journal of Veterinary Research. 2018;2(1):5-8.
17. Raquib A, Uddin MM, Chowdhury MS, Hossain MM, Rahman MM. Occurrence and distribution patterns of the diseases of goat in Dhaka, Bangladesh. Turkish Journal of Veterinary Research. 2020;4(2):51-6.

18. Balamurugan V, Das S, Raju DS, Chakravarty I, Nagalingam M, Hemadri D, Govindaraj G, Singh NI, Ltu K, Devi M, Sharma K. Prevalence of peste des petits ruminants in goats in North-East India. Virusdisease. 2014 Dec;25(4):488-92.

19. Nath TC, Bhuiyan MJ, Mamun MA, Datta R, Chowdhury SK, Hossain M, Alam MS. Common infectious diseases of goats in Chittagong district of Bangladesh. International Journal of Scientific Research in Agricultural Sciences. 2014;1(3):43-9.

20. Sarker S, Islam MH. Prevalence and risk factor assessment of Peste des petits ruminants in goats in Rajshahi, Bangladesh. Veterinary world. 2011 Dec 1;4(12):546.

21. Alemnew E, Yitagesu E, Addis H, Areaya A. Retrospective epidemiological study on goat disease in Debre birhan agricultural Research center Ataye boer breeding, evaluation and distribution site, North Shoa, Ethiopia. Biomedicine and Nursing. 2020;6(1):1-0.

22. Mekibib B, Mikir T, Fekadu A, Abebe R. Prevalence of pneumonia in sheep and goats slaughtered at Elfora Bishoftu export abattoir, Ethiopia: A pathological investigation. Journal of veterinary medicine. 2019;2019.

23. Karim MR, Parvin MS, Hossain MZ, Islam MT, Hussan MT. A report on clinical prevalence of diseases and disorders in cattle and goats at the upazilla veterinary hospital, mohammadpur, magura. Bangladesh Journal of Veterinary Medicine. 2014 Sep 16;12(1):47-53.

24. Lucky NS, Hossain MK, Roy AC, Haque MM, Uddin AM, Islam MM, Howlader MM. A longitudinal study on clinical diseases and disorders of cattle and goats in Sylhet, Bangladesh. Journal of Advanced Veterinary and Animal Research. 2016 Apr 15;3(1):24-37.

25. Sardar SA, Samad MA, Ehsan MA, Anower AK. Incidence of goat diseases in the selected area of Dhaka and Mymensingh districts. Journal of the Bangladesh Agricultural University. 2006;4(4522018-3915):299-304.

26. Tuli DE, Poddar S, Sultana J, Akter S, Sutradhar BC. Prevalence of clinical diseases and disorders of goat at Upazilla Veterinary Hospital, Pirojpur, Bangladesh. Turkish Journal of Veterinary Research. 2018;2(1):9-13.

27. Scharko P. Goat Health Management Tips. University of Kentucky Extension. 2008.

28. Gabli Z, Djerrou Z, Abd Elhafid Gabli MB. Prevalence of mastitis in dairy goat farms in Eastern Algeria. Veterinary world. 2019 Oct;12(10):1563.

29. Hepworth K. Managing internal parasitism in sheep and goats. 2006. 